\title{
Leitthema
}

Gefässchirurgie 2018 23 (Suppl 1):S23-S31 https://doi.org/10.1007/s00772-018-0390-z Published online: 6 June 2018

(C) The Author(s) 2018

CrossMark

\author{
A. Wiegering ${ }^{1,2} \cdot$ D. Liebetrau' $\cdot$ S. Menzel ${ }^{1} \cdot$ C. Bühler' $\cdot$ R. Kellersmann' • \\ U. A. Dietz ${ }^{1,3}$ \\ 'Klinik und Poliklinik für Allgemein-, Viszeral-, Gefäß- und Kinderchirurgie, Universitätsklinikum \\ Würzburg, Würzburg, Germany \\ ${ }^{2}$ Lehrstuhl für Biochemie und Molekularbiologie, Universität Würzburg, Würzburg, Germany \\ ${ }^{3}$ Klinik für Viszeral-, Gefäss- und Thoraxchirurgie, Kantonsspital Olten, Olten, Switzerland
}

\section{The incidence of incisional hernia after aortic aneurysm is not higher than after benign colorectal interventions}

\section{A retrospective control-matched cohort study}

\section{Introduction}

The development of incisional hernia following abdominal surgery is an undesired and, depending on the findings, high-risk event. Its incidence ranges between $2 \%$ and $15 \%$ in the literature [1-3]. There are a number of theories on the etiology of incisional hernia, with the techniques of abdominal closure and collagen metabolism being the two most important. The latter is based on the assumption that the development of incisional hernia is triggered by a disproportion of type I collagen to type III $[4,5]$. It was also long suspected that aortic aneurysms were caused by a collagen defect [6] and that these patients were at particularly high risk for developing incisional hernia; however, according to the current state of knowledge on the development of aortic aneurysms, collagen metabolism is no longer considered to be a major triggering factor. Thus, from a clinical perspective, the hypothesis can be pos-

The authors A. Wiegering, D. Liebetrau und S. Menzel share first authorship.

Updated English version of the German original publication.

The German version of this article can be found under https://doi.org/10.1007/s00772018-0372-1. tulated that the incidence of incisional hernia following medial xiphopubic laparotomy is not higher in abdominal aortic aneurysm patients than in matched controls with benign colorectal disease.

This hypothesis is based on the following rationales:

a) Incisional hernias develop differently depending on the incision and need to be differentially classified and grouped. Medial xiphopubic laparotomy is performed for abdominal aortic surgery. Therefore, it is essential that this patient group be compared exclusively with a control group that has also undergone medial xiphopubic laparotomy; patients serving as the control group should have no recognizable endogenous risk factors for incisional hernia [7].

b) From an historical perspective, it is assumed that the pathogenesis of abdominal aortic aneurysms (AAA) is based on impaired collagen production, which, at the same time as being an endogenous risk factor, also increases the risk of incisional hernias [6].

c) The pathogenesis of AAA remains unclear. Novel experimental investigations show that it is probably not caused by a collagen defect as previ- ously assumed [8] but arises instead from the Tunica intima.

d) As a result, the historical assumption that the increased incidence of incisional hernia in aortic aneurysm patients is due to a collagen defect needs to be reviewed, and the incisional hernia incidence in this patient group can possibly be attributed to some other causality.

\section{) Collagen deficency is probably not the etiology of abdominal aortic aneurysms}

In order to answer the working hypothesis, this article examines the following questions:

a) Are there differences in the incidence of incisional hernia at 1 year (primary endpoint) between the two groups?

b) What are the differences between the two groups in terms of the secondary endpoints: operating time, intensive care stay, postoperative complications, and inpatient stay?

c) What perspectives result from answering the study question in terms of further clinical and experimental research? 
Table 1 Patient collective

\begin{tabular}{|c|c|c|c|c|c|c|}
\hline \multirow[t]{2}{*}{ Patient collective } & \multicolumn{2}{|c|}{ Patients } & \multicolumn{2}{|c|}{ Aortic aneurysm } & \multicolumn{2}{|c|}{ Colorectal procedure } \\
\hline & $n$ & $\%$ & $n$ & $\%$ & $n$ & $\%$ \\
\hline Total & 499 & 100 & 96 & - & 403 & - \\
\hline Patients included & 99 & 19.8 & 72 & 75 & 27 & 6.7 \\
\hline Excluded & 400 & 80.2 & 24 & 25 & 367 & 93.3 \\
\hline $\begin{array}{l}\text { Failed to meet inclu- } \\
\text { sion criteria }\end{array}$ & 345 & 86.3 & 5 & 20.8 & 340 & 90.4 \\
\hline Deceased & 37 & 9.3 & 17 & 70.8 & 20 & 5.3 \\
\hline $\begin{array}{l}\text { No primary fascial } \\
\text { closure }\end{array}$ & 7 & 1.8 & - & - & 7 & 1.9 \\
\hline Loss to follow-up & 11 & 2.8 & 2 & 8.4 & 9 & 2.4 \\
\hline
\end{tabular}

\section{Patients and methods}

The study cohort comprised all patients undergoing a surgical aortic aneurysm procedure or colorectal procedure at the Surgical Department of the University Hospital of Würzburg between 1 January 2006 and 31 December 2008. Due to the differing surgical indications, the patient cohort comprising 499 cases was divided into two groups for comparison, with 96 cases belonging to the aortic aneurysm group and 403 cases to the colorectal procedure group.

In order to ensure comparability of the two groups, the following inclusion criteria were used to achieve a valid matched control. The inclusion criteria were: age $>57$ and $<77$ years (MW \pm SD of age in the AAA group), medial xiphopubic laparotomy (European Hernia Society [EHS] classification: $\mathrm{M} 1+\mathrm{M} 2+\mathrm{M} 3+\mathrm{M} 4+\mathrm{M} 5)$, and benign resected tissue on histology [9].

A total of 96 cases were evaluated in the aortic aneurysm group. Of the 24 cases that were excluded, 17 had already died by the time the study was conducted and no post-operative follow-up had been documented. In a further two cases, no followup dates could be determined despite attempts to contact these patients both in writing and by telephone. The remaining five cases that were excluded consisted of: one case that was reported twice, one case declared to be an aortic aneurysm but which was treated with a colorectal procedure, one case in which an aortic aneurysm and the colon were operated on in a single-stage approach and two cases in which the indications for aortic aneurysm repair using stent grafts were established. This left a total of 72 complete records for evaluation.

The colorectal procedure group comprised 403 potential cases. Once the inclusion criteria and the abovementioned age matching ( $>57$ and $<77$ years) had been applied, 63 cases remained. Of these 63 cases, 20 had already died by the time the study was conducted and no post-operative follow-up had been documented. In a further nine cases, no follow-up date could be determined despite attempts to contact these patients both in writing and by telephone. A further seven cases were excluded as they had not undergone primary abdominal wall closure. This left a total of 27 complete records for evaluation (• Table 1; • Fig. 1).

\section{Preoperative data}

The surgical indications in the aortic aneurysm group were symptomatic aortic aneurysm or aneurysm measuring over $5 \mathrm{~cm}$ in diameter and showing annual progressive growth of over $0.5 \mathrm{~cm}$ in diameter. Patients in the colorectal group were selected on the basis of the appropriate surgical procedure, verification in the surgical report that a medial xiphopubic laparotomy had indeed been performed, and exclusion of oncological disease.

The risk factors for the development of incisional hernia were determined. Preoperative risk factors included: male gender, obesity with a body mass index (BMI) of over $30 \mathrm{~kg} / \mathrm{m}^{2}$, nicotine use, diabetes mellitus, hypertension, kidney failure, cortisone use, lung disease, preoperative hemoglobin below $10 \mathrm{~g} / \mathrm{dl}$, preoperative albumin below $3.5 \mathrm{~g} / \mathrm{dl}$, a known pre-existing hernia, known cancer, collagen disorders, emergency surgical procedures, known previous surgery, as well as a second procedure within 1 month. Pulmonary diseases included chronic obstructive pulmonary disease (COPD), chronic bronchitis, and bronchial asthma. Postoperative risk factors were divided into two categories: particular features of the postoperative course and postoperative complications $[2,10]$.

\section{Medial laparotomy and abdominal closure in both patient groups}

Laparotomy was performed using a skin incision around the left side of the umbilicus from below the xiphoid process to immediately above the pubic symphysis; incision of subcutaneous tissue and sparing exposure of the linea alba; dividing the linea alba with a scalpel and opening the peritoneum.

Abdominal wall closure was performed using a continuous absorbable monofilament 1-USP loop suture while maintaining a suture-to-wound length ratio of 4:1 [11]. At least two loops were used: starting in the suprapubic region, the first was used as a continuous suture to the navel, and the second, beginning in the subxiphoid region, also as a continuous suture to the umbilicus, where the two loops were knotted together. After rinsing the subcutis with saline solution, a subcutaneous redon drain was placed and the skin incision closed using polypropylene USP 3-0 Donati stitches. The precise length or distance from the xiphoid process to the symphysis was not routinely measured.

\section{Primary outcome}

The occurrence of incisional hernia was defined as the primary endpoint. The follow-up date was determined from the previous medical report and any available diagnostic computed tomography (CT) images were also evaluated in the diagnosis. The date of the CT scan was set as the follow-up date. If no postoperative 
Gefässchirurgie 2018 · 23 (Suppl 1):S23-S31 https://doi.org/10.1007/s00772-018-0390-z

(c) The Author(s) 2018

\author{
A. Wiegering · D. Liebetrau · S. Menzel · C. Bühler · R. Kellersmann · U. A. Dietz
}

\title{
The incidence of incisional hernia after aortic aneurysm is not higher than after benign colorectal interventions. A retrospective control-matched cohort study
}

\begin{abstract}
Background. Abdominal aortic aneurysms

(AAA) have most probably an inflammatory origin, whereby the elastica is the layer actually involved. In the past, collagen weackness was supposed to be the shared cause of both, AAA and incisional hernias. Since the development of new techniques of closure of the abdominal wall over the last decade, collagen deficency seems to play only a secondary etiologic role.

Objectives. The aim of the study was to investigate whether the incidence of incisional hernia following laparotomy due to AAA differs from that of colorectal interventions. Material and methods. This was a retrospective control matched cohort study. After screening of 403 patients with colorectal
\end{abstract}

interventions and 96 patients with AAA, 27 and 72 patients, respectively were included. The match criteria for inclusion of patients with colorectal interventions were: age, benign underlying disease and median xiphopubic laparotomy. The primary endpoint was the incidence of an incisional hernia. The secondary endpoints were the risk profile, length of stay in the intensive care unit and postoperative complications. Data analysis was carried in the consecutive collective from 2006 to 2008.

Results. In the group with AAA the mean follow-up was $34.5 \pm 18.1$ months and in the group with colorectal interventions $35.7 \pm 21.4$ months. The incidence of incisional hernias showed no significant differences between the two groups. In the AAA group 10 patients (13.8\%) developed an incisional hernia in contrast to 7 patients in the colorectal intervention group (25.9\%).

Conclusions. In our collective patients with AAA did not show an increased incidence of incisional hernia in comparison to patients with colorectal interventions with comparable size of the laparotomy access and age. The quality of closure of the abdominal wall seems to be an important factor for the prevention of incisional hernia.

Keywords

Benign colon resection - Abdominal wall closure $\cdot$ Abdominal aortic aneurysm . Incisional hernia $\cdot$ Median laparotomy

\section{Die Inzidenz von Narbenhernien nach Aortenaneurysma ist nicht höher als nach benignen kolorektalen Eingriffen. Eine retrospective Matched-control-Kohortenstudie}

\section{Zusammenfassung}

Hintergrund. Das abdominelle Aortenaneurysma (AAA) hat eine inflammatorische Genese, wobei die Elastica die eigentlich beteiligte Schicht ist. In den vergangenen Jahrzehnten galt die Hypothese, dass die Kollagenqualität für beide, AAA und Narbenhernien verantwortlich sei. Mit der Entwicklung neuer Techniken des Bauchdeckenverschlusses im Laufe der letzten Jahrzehnte, scheint die Bedeutung des defizitären Kollagens als kausale Ursache abgenommen zu haben.

Fragestellung. Die Studie geht der Frage nach, ob sich die Inzidenzrate von Narbenhernien nach Laparotomie aufgrund eines AAA oder kolorektalen Eingriffs unterscheidet.

Material und Methoden. Dies ist eine retrospektive Matched-control-Kohortenstudie.
Nach Screening von 403 kolorektalen Patienten und 96 AAA Patienten wurden 27 und 72 Patienten eingeschlossen. Match-Kriterien für den Einschluss kolorektaler Patienten waren: Alter, benigne Grunderkrankung und median-xiphopubische Laparotomie. Das primäre Ergebnis war die Inzidenz einer Narbenhernie im Verlauf. Sekundäre Ergebnisse waren das Risikoprofil, der Aufenthalt auf Intensivstation und postoperative Komplikationen. Die Datenanalyse erfolgte im konsekutiven Kollektiv der Jahre 2006 bis 2008.

Ergebnisse. In der Gruppe der AAA betrug das mittlere Follow-up 34,5 $\pm 18,1$ Monate, in der Gruppe der kolorektalen Eingriffe 35,7 $\pm 21,4$ Monate. Die Narbenhernieninzidenz in beiden Gruppen unterschied sich nicht signifikant:
In der AAA-Gruppe hatten 10 Patienten $(13,8 \%)$ eine Narbenhernie entwickelt, wohingegen 7 kolorektale Patienten (25,9\%) eine Narbenhernie ausbildeten.

Schlussfolgerungen. Im eigenen Patientenkollektiv haben Patienten mit AAA im Vergleich zu kolorektalen Patienten mit vergleichbar großem Laparotomiezugang und Alter keine erhöhte Narbenhernieninzidenz. Die Qualität des Bauchdeckenverschlusses scheint ein wichtiger Faktor bei der Prävention der Narbenhernie zu sein.

\section{Schlüsselwörter}

Kolonresektion - Bauchdeckenverschluss . Aortenaneurysma $\cdot$ Narbenhernie $\cdot$ Mediane Laparotomie course had been documented, patients were contacted in writing.

\section{Secondary outcomes}

Postoperative complications were divided into two categories. Postoperative risk factors were assigned to an "intensive medicine" category and a "non-intensive medicine" category. The former included wound infections, catecholamine ther- apy, relaparotomy, artificial ventilation, and the length of stay on the intensive care unit. Non-intensive medical complications included infections, seroma, and secondary wound healing. These complications were classified according to the Clavien-Dindo classification [12].

\section{Follow-up examination}

Follow-up examinations of patients after AAA repair were planned for 3, 6, and 12 months as standard at the Surgical Department of the University Hospital Würzburg. Following benign colorectal procedures, patients were examined at 1 year. Patients who did not attend follow-up at the University Hospital Würzburg were contacted in writing 


\section{Leitthema}

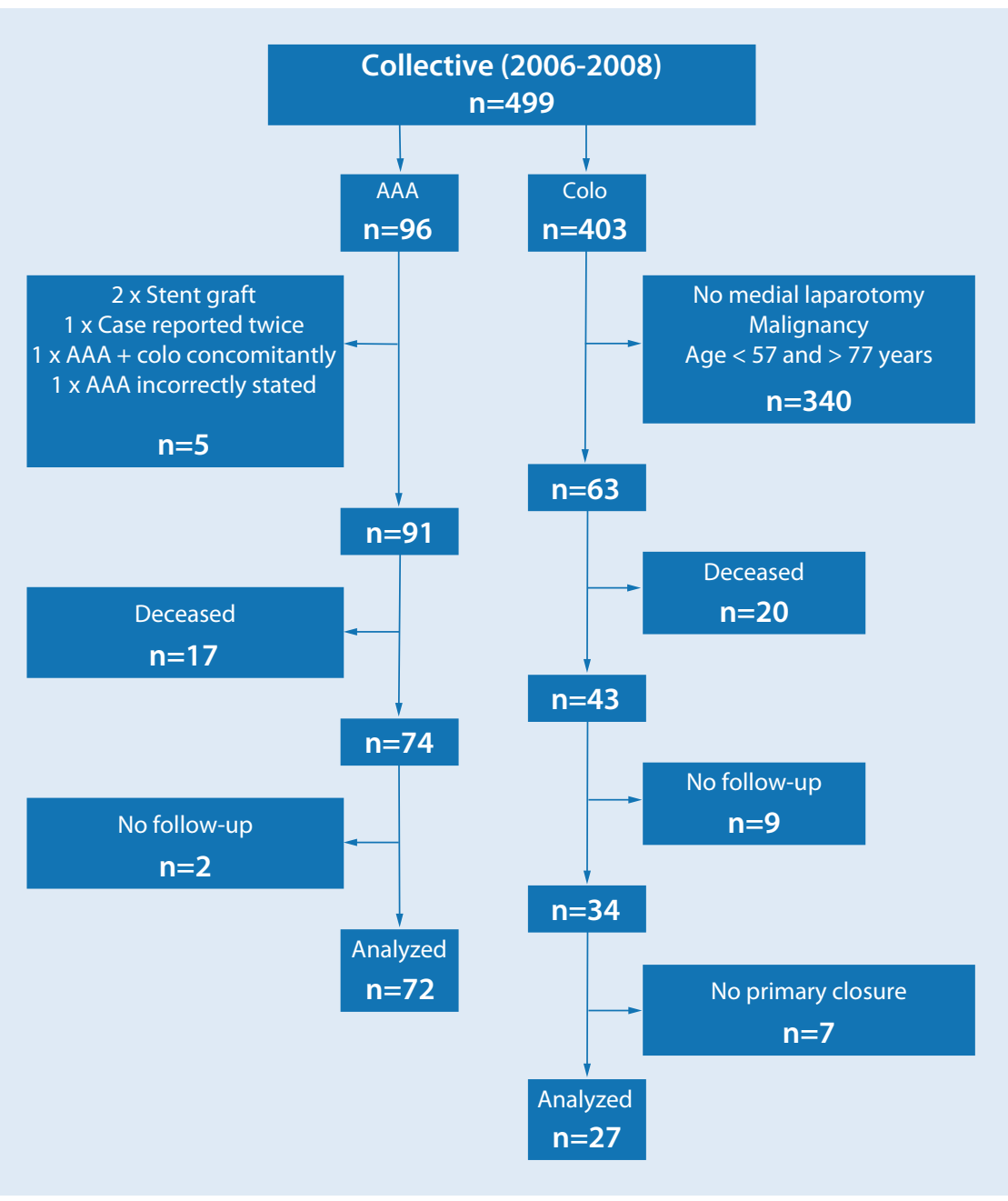

and asked to complete a questionnaire. Beyond the 12-month period, the latest clinical outcome of medial abdominal wall closure was noted.

\section{Statistics}

Data were collected in an $\mathrm{Excel}^{\circledR}(\mathrm{Mi}$ crosoft, Redmon, WA, USA) table and then coded. Statistical analysis was carried out using SPSS Statistic $24^{\circledR}$ (IBM, Armonk, NY, USA). In all, 99 records were analyzed in which follow-up could be determined. In the univariate analysis, the relevance of the individual factors was calculated in a statistical paired comparison using the exact Fisher test. This made it possible to determine whether two variables were independent of or dependent on each other. The relationship was considered significant at a bilateral significance level of $p<0.05$ and nonsignificant (ns) at $p>0.05$. To illustrate the distribution of some of the values, mean and median values were determined. As a measure for the dispersion of a random variable, the standard deviation around its mean was used. Mean values were compared using the nonparametric Mann-Whitney test.

\section{Outcomes}

Fig. 1 A Patient flow diagram ( $A A A$ abdominal aortic aneurysm, Colo colorectal procedure)

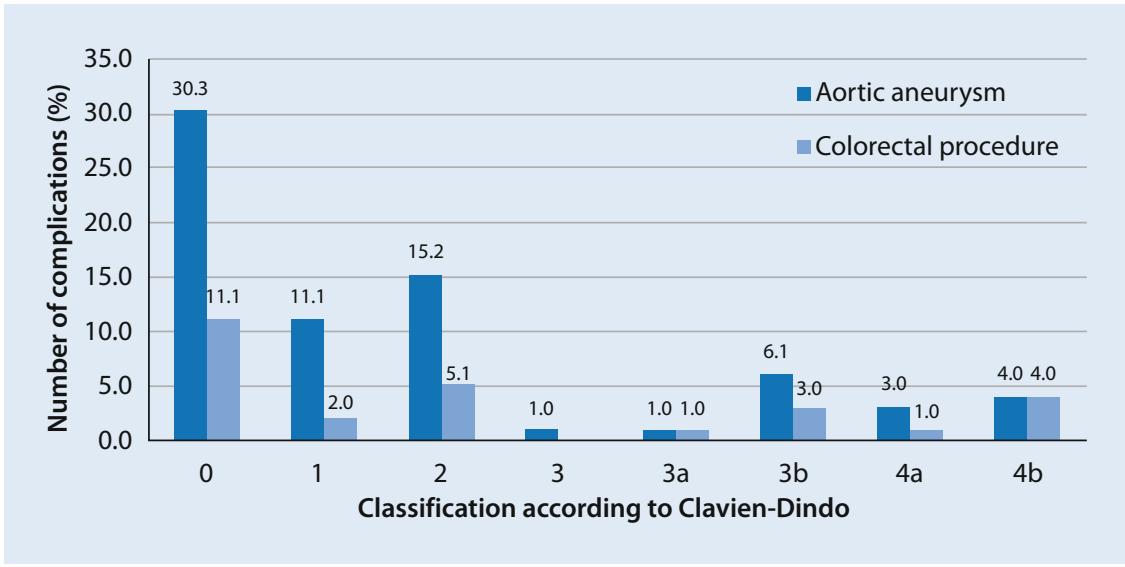

Fig. $2 \Delta$ Overview of the distribution of postoperative complications according to Clavien and Dindo in relation to the diagnosis [12]. No significant differences were seen between the two groups. No postoperative classification could be determined for one patient. This is not shown for reasons of clarity

Outcomes were collected for 69 patients from the prospective electronic medical records (51/18 AAA/colorectal, respectively). Current $\mathrm{CT}$ images of the abdomen were available for $10 / 7 \mathrm{pa}$ tients, respectively; these were used to objectively investigate the clinical diagnosis "no incisional hernia" or "incisional hernia". A total of 30 patients were contacted via questionnaire. Mean follow-up in the aortic aneurysm group was $34.5 \pm 18.1$ months and $35.7 \pm 21.4$ months in the colorectal procedure group. No significant difference could be seen between the two groups in terms of mean follow-up in months.

- Table 2 shows the age and gender distribution between the patient groups. There were significantly more females in the colorectal procedure group compared with the aortic aneurysm group. 


\begin{tabular}{|c|c|c|c|c|}
\hline Patient cohort $(n=99)$ & Total & AAA & Colo & $p$-value \\
\hline Sex (male/female) & $77 / 22$ & $63 / 9$ & $14 / 13$ & $<0.05$ \\
\hline Age in years $(M \pm S D)$ & $67.7 \pm 8$ & $67.8 \pm 8.6$ & $67.4 \pm 5.9$ & n.s. \\
\hline Median age (years) & 68 & 68 & 67 & - \\
\hline Preoperative hemoglobin $(\mathrm{g} / \mathrm{dl} \pm \mathrm{SD})$ & $13.6 \pm 2.2$ & $14.11 \pm 2.1$ & $12.1 \pm 1.9$ & $<0.05$ \\
\hline Preoperative albumin $(g / d l \pm S D)$ & $4 \pm 0.6$ & $4.2 \pm 0.6$ & $3.6 \pm 0.7$ & $<0.05$ \\
\hline$A S A$ score $\pm S D$ & $2.7 \pm 0.7$ & $2.8 \pm 0.7$ & $2.6 \pm 0.7$ & n.s. \\
\hline - Maximum value & 5 & 5 & 4 & - \\
\hline - Minimum value & 1 & 2 & 1 & - \\
\hline - Median & 3 & 3 & 3 & - \\
\hline Surgery time $(\min \pm S D)$ & $240.2 \pm 135.1$ & $266.6 \pm 148$ & $169.6 \pm 42.5$ & $<0.05$ \\
\hline$I C U$ (days $\pm S D$ ) & $5.2 \pm 15.9$ & $4 \pm 9.8$ & $8.5 \pm 26$ & $<0.05$ \\
\hline $\begin{array}{l}\text { Postoperative inpatient stay } \\
(\text { days } \pm S D)\end{array}$ & $18.8 \pm 16.9$ & $17.3 \pm 11.5$ & $22.6 \pm 26.5$ & n.s. \\
\hline
\end{tabular}

\section{Table 3 The incidence of incisional hernia}

\begin{tabular}{|c|c|c|c|c|c|c|c|}
\hline \multirow{2}{*}{$\begin{array}{l}\text { Patient collective } \\
(n=99)\end{array}$} & \multicolumn{2}{|c|}{ Total } & \multicolumn{2}{|c|}{ AAA } & \multicolumn{2}{|c|}{ Colo } & \multirow[t]{2}{*}{$p$-Value } \\
\hline & $n$ & $\%$ & $n$ & $\%$ & $n$ & $\%$ & \\
\hline Patients & 99 & 100 & 72 & - & 27 & - & - \\
\hline Hernia in general & 17 & 17.2 & 10 & 13.9 & 7 & 25.9 & n.s. \\
\hline $\begin{array}{l}\text { Hernia before } 180 \\
\text { days }\end{array}$ & 4 & 4 & 3 & 4.2 & 1 & 3.7 & n.s. \\
\hline Hernia after 180 days & 13 & 13.1 & 7 & 9.7 & 6 & 22.2 & n.s. \\
\hline
\end{tabular}

Table 4 The incidence of incisional hernia $(\mathrm{IH})$ in relation to diagnosis and sex

\begin{tabular}{|c|c|c|c|c|c|c|c|}
\hline & \multicolumn{2}{|c|}{ No IH } & \multicolumn{2}{|l|}{ IH } & \multirow[t]{2}{*}{$p$-value } & \multirow[t]{2}{*}{ Relative risk } & \multirow{2}{*}{$\begin{array}{l}\text { Confidence } \\
\text { interval } \\
(0.95)\end{array}$} \\
\hline & $n$ & $\%$ & $n$ & $\%$ & & & \\
\hline Patients included & - & - & 17 & 100 & - & - & - \\
\hline Aortic aneurysm & 62 & 75.6 & 10 & 58.8 & n.s. & 0.778 & $0.513-1.180$ \\
\hline Colorectal & 20 & 24.4 & 7 & 41.2 & n.s. & 1.688 & $0.852-3.346$ \\
\hline Male & 62 & 75.6 & 15 & 88.2 & n.s. & 0.482 & $0.124-1.873$ \\
\hline Female & 20 & 24.4 & 2 & 11.8 & n.s. & 1.167 & $0.943-1.444$ \\
\hline
\end{tabular}

\section{Primary outcome: Incisional hernia development}

- Table 3 shows the incidence of incisional hernia in relation to the time of diagnosis and primary surgical procedure. The overall rate of incisional hernia was $17.2 \%: 4.0 \%$ of all patients developed a hernia within 180 days and $13.1 \%$ after 180 days. In all, $13.9 \%$ of the AAA group and $25.9 \%$ of the colorectal procedure group developed incisional hernia. There was no significant difference be- lowing colorectal resection. Here again, there is no significant correlation between risk factors and the incidence of incisional hernia (• Table 6).

\section{Secondary outcomes}

Postoperative complications are shown in - Table 7. None of the postoperative complications in either group affected the development of incisional hernia. • Fig. 2 shows the distribution of postoperative complications according to severity in line with the CDC [12]; these were also comparably distributed in both cohorts. No significant differences were seen in terms of the incidence of incisional hernia and postoperative non-intensive medical complications. The relative risk of developing an incisional hernia in the case of complications requiring revision was increased by $34 \%$, without, however, reaching significance in this collective.

\section{Discussion}

\section{Key messages of the study}

The matched-control comparison revealed no differences between the two groups in relation to the primary endpoint, i.e., the development of incisional hernia. The incidence of incisional hernia following aortic aneurysm surgery tended to be even lower compared with the colorectal group. According to Clavien-Dindo score, complications in both groups were comparable. In neither group was it possible to establish and influence of the postoperative course and postoperative complications on the development of incisional hernia. These results confirm earlier results obtained by Israelsson [11], who found that patients do not have a greater risk for incisional hernia following aortic aneurysm repair than patients following colorectal procedures with accesses of similar dimensions.

\section{Evaluation and critical review of own results}

The surgical technique of abdominal wall closure is of crucial importance for the postoperative incidence of incisional hernia. In this study, an incidence rate of 
Table 5 The incidence of incisional hernia (IH) in aortic aneurysm (AAA) patients depending on preoperative risk factors

\begin{tabular}{|l|l|l|l|l|l|}
\multicolumn{2}{|l|}{ AAA (total) } & \multicolumn{2}{|l|}{ No IH } & IH & \\
& $\%$ & $\boldsymbol{n}$ & $\%$ & $\boldsymbol{n}$ & $\%$ \\
\hline
\end{tabular}

p-Value Relative Confidence risk interval (0.95)

\begin{tabular}{|c|c|c|c|c|c|c|c|c|c|}
\hline Patients & 72 & 100 & - & - & - & - & - & - & - \\
\hline Male gender & 63 & 87.5 & 53 & 85.5 & 10 & 100 & n.s. & 1.18 & $1.056-1.296$ \\
\hline Age $>50$ years & 72 & 100 & 62 & 100 & 10 & 100 & n.s. & - & - \\
\hline $\mathrm{BMI}>30 \mathrm{~kg} / \mathrm{m}^{2}$ & $3^{a}$ & 4.3 & 3 & 5 & 0 & 0 & n.s. & - & - \\
\hline Nicotine use & 34 & 47.2 & 30 & 48.4 & 4 & 40 & n.s. & 0.827 & $0.371-1.842$ \\
\hline $\begin{array}{l}\text { Diabetes melli- } \\
\text { tus }\end{array}$ & 10 & 13.9 & 9 & 14.5 & 1 & 10 & n.s. & 0.689 & $0.098-4.866$ \\
\hline Hypertension & 57 & 79.2 & 48 & 77.4 & 9 & 90 & n.s. & 1.163 & $0.909-1.487$ \\
\hline Renal failure & 13 & 18.1 & 10 & 16.1 & 3 & 30 & n.s. & 1.86 & $0.617-5.609$ \\
\hline Cortisone use & 12 & 16.7 & 11 & 17.7 & 1 & 10 & n.s. & 0.564 & $0.081-3.903$ \\
\hline $\begin{array}{l}\text { Malignant } \\
\text { (previous) } \\
\text { disease }\end{array}$ & 3 & 4.2 & 3 & 4.8 & 0 & 0 & n.s. & - & - \\
\hline Lung disease & 17 & 23.6 & 14 & 22.6 & 3 & 30 & n.s. & 1.329 & $0.464-3.808$ \\
\hline $\begin{array}{l}\text { Collagen dis- } \\
\text { ease }\end{array}$ & - & - & - & - & - & - & - & - & - \\
\hline $\begin{array}{l}\text { Preoperative } \\
\mathrm{Hb}<10 \mathrm{~g} / \mathrm{dl}\end{array}$ & $3^{b}$ & 4.2 & 2 & 3.3 & 1 & 10 & n.s. & 3.05 & $0.304-30.587$ \\
\hline $\begin{array}{l}\text { Preoperative } \\
\text { albumin } \\
<3.5 \mathrm{~g} / \mathrm{dl}\end{array}$ & $4^{c}$ & 9.3 & 3 & 8.3 & 1 & 14.3 & n.s. & 1.714 & $0.207-4.188$ \\
\hline $\begin{array}{l}\text { History of } \\
\text { hernia }\end{array}$ & 7 & 9.7 & 7 & 11.3 & 0 & 0 & n.s. & - & - \\
\hline $\begin{array}{l}\text { 2nd Proce- } \\
\text { dure/1 month }\end{array}$ & 13 & 18.1 & 9 & 14.5 & 4 & 40 & n.s. & 2.756 & $1.044-7.270$ \\
\hline $\begin{array}{l}\text { Emergency } \\
\text { surgery }\end{array}$ & 10 & 13.9 & 8 & 12.9 & 2 & 20 & n.s. & 1.55 & $0.383-6.274$ \\
\hline $\begin{array}{l}\text { Previous } \\
\text { abdominal } \\
\text { surgery }\end{array}$ & 16 & 22.2 & 15 & 24.2 & 1 & 10 & n.s. & 0.413 & $0.061-2.794$ \\
\hline \multicolumn{10}{|c|}{$\begin{array}{l}\text { BMI body mass index, } H b \text { hemoglobin, } n \text {.s. not significant } \\
{ }^{a} n \text { (valid) }=70 \\
{ }^{n} n \text { (valid) }=71 \\
{ }^{c} n \text { (valid) }=43\end{array}$} \\
\hline
\end{tabular}

$13.9 \%$ was seen in the aortic aneurysm group. Incidence rates of between $6 \%$ [11] and 35\% in aortic aneurysm patients are reported in the literature $[11,13,14]$. The not significantly higher rate of incisional hernia in the colorectal group, as well as the longer stay in the intensive care unit, can probably be accounted for by underlying diseases, such as sigmoid diverticulitis in this cohort. The most important weaknesses of this study are its retrospective data collection and the low patient number; however, it will not become easier to include patients undergoing open aortic aneurysm repair in studies in the future, given that endovas- in a highly homogeneous and comparable study population.

\section{Explanatory models for the development of incisional hernia and aortic aneurysm}

Collagen I and III play a particularly important role in scar formation: collagen III is metabolized primarily in the early phase of scar formation, collagen I in the late phase [15]. Collagen I is essential for scar stability. It is known that hernia patients have a lower collagen I:III ratio in favor of predominantly high collagen III $[4,5,16]$. An increased incidence of incisional hernia has also been observed in hereditary diseases involving collagen defects [17-20]. Matrix metalloproteases (MMP) play a crucial role in the alteration of collagens. They are particularly important in the regulation of growth and apoptotic processes [21, 22]. There appears to be significant overexpression of MMP-2 in incisional hernia [23]. Since collagen synthesis can be suppressed by inflammatory processes, such as postoperative sepsis, the functionality of the various MMP and collagens may be impaired by the wound milieu [24]. Current models of the development of aortic aneurysm work on the premise that the pathogenesis of aortic aneurysms is not based on a collagen defect as previously assumed [6]: an elastase defect has been postulated [8], while more recent experimental studies also focused on inflammation as the cause of aortic wall weakening during the process of aneurysm development [25]. Ultimately, the molecular etiology of aneurysm development remains unclear; however, the collagen weakness assumed in the past to be the cause of AAA is highly unlikely according to current knowledge.

\section{Taking a careful approach to abdominal wall closure}

One possible factor that affects the low incidence of incisional hernia following aortic surgery in the authors' department is related to the fact that the vascular surgeons there have broad general surgical training. The importance of meticulous abdominal wall closure cannot be disregarded in this context. Evidence shows that maintaining a suture length-wound 
Table 6 The incidence of incisional hernia $(\mathrm{IH})$ in colorectal procedures depending on preoperative risk factors

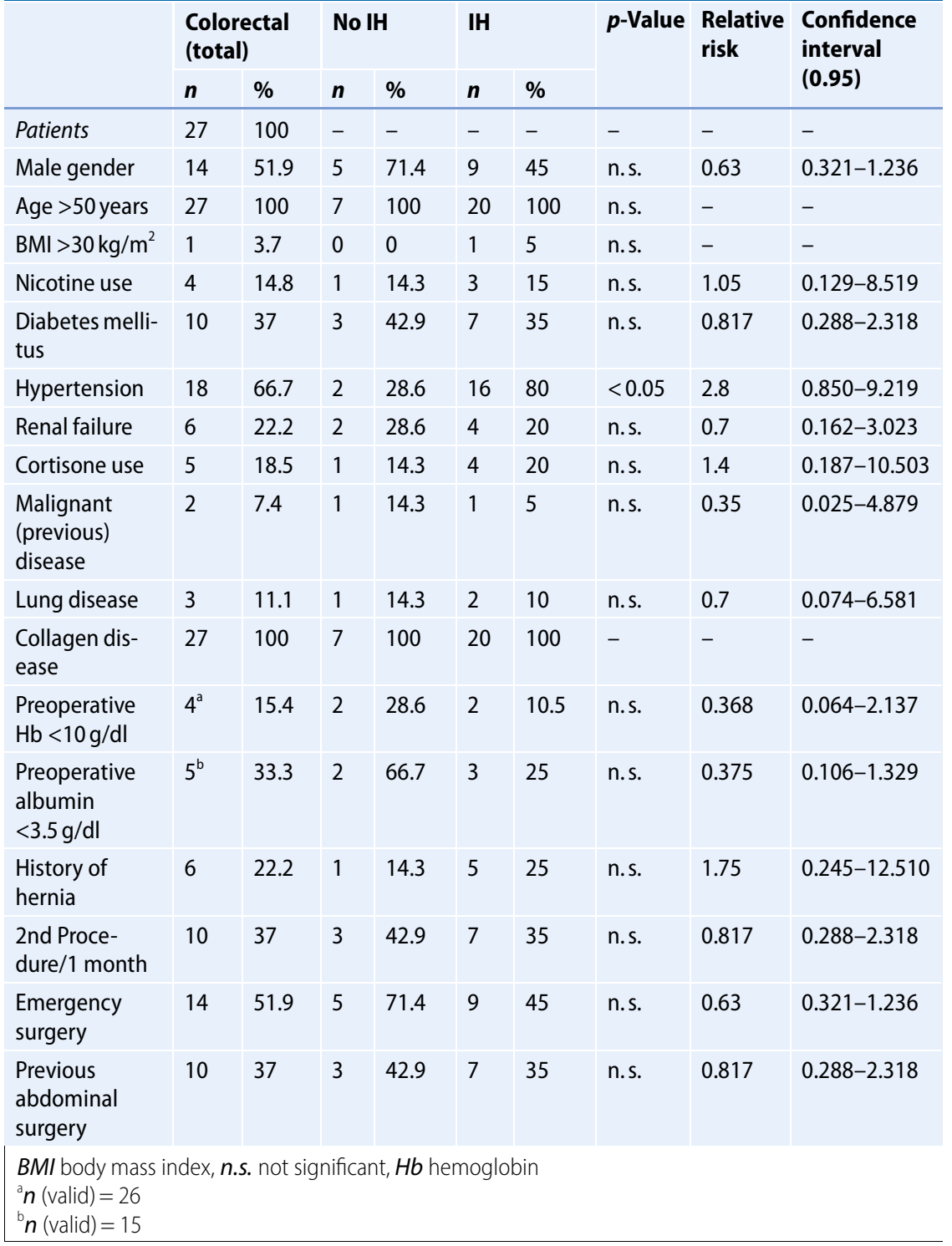

Table 7 The incidence of postoperative complications in the aortic aneurysm (AAA) and colorectal groups

\begin{tabular}{|l|l|l|l|l|l} 
& AAA & \multicolumn{2}{l}{ Colorectal } & p-Value \\
& $\boldsymbol{n}$ & $\%$ & $\boldsymbol{n}$ & $\%$ & \\
\hline Complications/patients & 72 & 100 & 27 & 100 & - \\
\hline No complications & 30 & 41.7 & 11 & 40.7 & n.s. \\
\hline Wound infection & 11 & 15.3 & 9 & 33.3 & n.s. \\
\hline Seroma & 2 & 2.8 & 0 & 0 & n.s. \\
\hline Secondary wound healing & 3 & 4.2 & 5 & 18.5 & n.s. \\
\hline Oral anticoagulation & 65 & 90.3 & 12 & 44.4 & n.s. \\
\hline Other complications & 35 & 48.6 & 13 & 48.1 & n.s. \\
\hline Complications requiring revision & 7 & 9.7 & 8 & 29.6 & n.s. \\
\hline n.s. not significant & & & & & \\
\hline
\end{tabular}

length ratio of $4: 1[26,27]$, using a continuous suture with slowly absorbable or non-absorbable suture material [26, 28-37], maintaining a distance from needle puncture to wound edge of at least $1 \mathrm{~cm}$ [30], as well as distances of less than $1 \mathrm{~cm}$ between two punctures [31], can reduce the incidence of incisional hernia. Ever since the publication of works by Israelsson in the mid 1990s, it has been the accepted wisdom that less can be more: by using smaller needles and small tissue bites, incisional hernia incidence in medial laparotomy following aortic aneurysm repair can be reduced from $21 \%$ to $10 \%(p<0.01)$, and to as little as $5.2 \%$ in selected patients $[11,31-33]$. Although a recent multi-center randomized study was not able to achieve quite these results, it confirmed the superiority of the small-bites technique (13\%) compared with the large-bites technique $(21 \%)$ at 1 year $(p=0.022$; OR 0.52 ; CI 95\% 0.31-0.87; $p=0.0131$ ) [34].

\section{Is prophylactic mesh placement beneficial in AAA?}

The surgical management of hernias has moved away from the conventional suture technique in recent years in favor of repair using mesh [35]. According to these positive results, it has been postulated that maybe prophylactic mesh placement could significantly reduce the incidence of incisional hernias in highrisk patients, for example, in obese patients. A recent meta-analysis of prophylactic mesh placement in the setting of open bariatric procedures also revealed a positive effect for mesh when the available cohort studies were included (OR 0.39 ; CI 95\% 0.13-0.68; $p=0.004$ ); however, if one considers only the four randomized controlled trials (RCT) included in the meta-analysis, prophylactic mesh placement conferred no benefit (OR 0.52; CI 95\% 0.24-1.16; $p=0.104$ ) [36]. That particular meta-analysis did not include the recently published RCT conducted by Muysoms et al. Here, the incidence of incisional hernia at 2 years (with approximately $10 \%$ loss to follow-up) in the control group (continuous suture using the large-bites technique) was $28 \%$ and in the prophylactic mesh group (retromus- 
cular mesh placement) $0 \%(p<0.001)$; however, retromuscular mesh placement is considerably more complex and the advantages of suture techniques are not exhausted with the large-bites control group [37]. This study needs to be re-interpreted and re-weighted in the light of the small-stitches technique.

In summary, it must be concluded that according to current evidence, the meticulousness of abdominal wall closure based on Israelsson's recommendations $[11,32]$ appears to be the most appropriate approach irrespective of the surgical indications.

\section{Conclusion}

- After abdominal operations the development of an undesired and, depending on the findings, a highrisk incisional hernia occurs in $2-15 \%$ of cases. Abdominal aortic aneurysms (AAA) have an inflammatory origin. According to the current state of knowledge collagen metabolism can be excluded as a trigger factor.

- Patients with AAA do not have an increased risk of incisional hernia in comparison to patients after a benign colorectal intervention. The incidence rates with respect to age, sex or risk factors do not show significant differences between both groups.

- The surgical technique for abdominal wall closure is of decisive importance for the postoperative incidence of incisional hernias. Postoperative complications had no influence on their formation.

There is a trend in the literature, suggesting that prophylactic implantation of a mesh may reduce the incidence of incisional hernias in patients at risk.

- The retrospective data collation and the low number of patients are weak points of this study; however, in the future it will not be easier to include patients with open treatment of aortic aneurysms in studies because now endovascular procedures have become the standard.

\section{Corresponding address

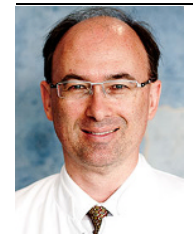 \\ Prof. Dr. U. A. Dietz \\ Klinik für Viszeral-, Gefäss- und Thoraxchirurgie, Kantonsspital Olten Baselstr. 150, 4600 Olten, Switzerland ulrich.dietz@spital.so.ch}

\section{Compliance with ethical guidelines}

Conflict of interest. A. Wiegering, D. Liebetrau, S. Menzel, C. Bühler, R. Kellersmann and U.A. Dietz declare that they have no competing interests.

This article does not contain any studies with human participants or animals performed by any of the authors.

The supplement containing this article is not sponsored by industry.

Open Access This article is distributed under the terms of the Creative Commons Attribution 4.0 International License (http://creativecommons.org/licenses/by/ 4.0/), which permits unrestricted use, distribution, and reproduction in any medium, provided you give appropriate credit to the original author(s) and the source, provide a link to the Creative Commons license, and indicate if changes were made.

\section{References}

1. Wissing J et al (1987) Fascia closure after midline laparotomy: results of a randomized trial. Br J Surg 74(8):738-741

2. Hoer J et al (2002) Factors influencing the development of incisional hernia. A retrospective study of 2,983 laparotomy patients over a period of 10 years. Chirurg 73(5):474-480

3. Mudge M, Hughes LE (1985) Incisional hernia: a 10 year prospective study of incidence and attitudes. BrJSurg 72(1):70-71

4. Casanova AB, Trindade EN, Trindade MR (2009) Collagen in the transversalis fascia of patients with indirect inguinal hernia: a case-control study. Am J Surg 198(1):1-5

5. Klinge U et al (2000) Abnormal collagen I to III distribution in the skin of patients with incisional hernia. Eur Surg Res 32(1):43-48

6. Anderson DW et al (1996) Multiple defects in type III collagen synthesis are associated with the pathogenesis of abdominal aortic aneurysms. Ann NYAcad Sci 800:216-228

7. Dietz UA, Hamelmann W, Winkler MS et al (2007) An alternative classification of incisional hernias enlisting morphology, body type and risk factors in the assessment of prognosis and tailoring of surgical technique. J Plast Reconstr Aesthet Surg 60(4):383-388

8. Shang T et al (2012) Inhibition of experimental abdominal aortic aneurysm in a rat model by way of tanshinone IIA. J Surg Res. https://doi.org/10. 1016/j.jss.2012.04.068
9. Muysoms FE, Miserez M, Berrevoet F et al (2009) Classification of primary and incisional abdominal wall hernias. Hernia 13:407-414

10. Hoer J et al (2002) Prevention of incisional hernia. Chirurg 73(9):881-887

11. Israelsson LA (1999) Incisional hernias in patients with aortic aneurysmal disease: the importance of suture technique. Eur J Vasc Endovasc Surg 17(2):133-135

12. Dindo D, Demartines N, Clavien PA (2004) Classification of surgical complications: a new proposal with evaluation in a cohort of 6336 patients and results of a survey. Ann Surg 240(2):205-213

13. Raffetto JD et al (2003) Incision and abdominal wall hernias in patients with aneurysm or occlusive aortic disease. JVasc Surg 37(6):1150-1154

14. Holland AJ et al (1996) Incisional hernias are more common in aneurysmal arterial disease. Eur J Vasc Endovasc Surg 12(2):196-200

15. Henriksen NA et al (2011) Connective tissue alteration in abdominal wall hernia. Br J Surg 98(2):210-219

16. Klinge $U$ et al (2001) Collagen I/III and matrix metalloproteinases MMP 1 and 13 in the fascia of patients with incisional hernias. J Invest Surg 14(1):47-54

17. Uden A, Lindhagen $T$ (1988) Inguinal hernia in patients with congenital dislocation of the hip. A sign of general connective tissue disorder. Acta Orthop Scand 59(6):667-668

18. Girotto JA et al (2000) Recurrent ventral herniation in Ehlers-Danlos syndrome. Plast Reconstr Surg 106(7):1520-1526

19. Liem MS et al (1997) Increased risk for inguinal hernia in patients with Ehlers-Danlos syndrome. Surgery 122(1):114-115

20. Rowe DW et al (1985) Diminished type I collagen synthesis and reduced alpha 11 collagen messenger RNA in cultured fibroblasts from patients with dominantly inherited type I osteogenesis imperfecta. J Clin Invest 76(2):604-611

21. Cauwe B, Van den Steen PE, Opdenakker G (2007) The biochemical, biological, and pathological kaleidoscope of cell surface substrates processed by matrix metalloproteinases. Crit Rev Biochem MolBiol 42(3):113-185

22. Lee MH, Murphy G (2004) Matrix metalloproteinases at a glance. JCell Sci 117(18):4015-4016

23. Rosch R et al (2006) Biomaterial-dependent MMP2 expression in fibroblasts from patients with recurrent incisional hernias. Hernia 10(2):125-130

24. Ahrendt GM, Tantry US, Barbul A (1996) Intraabdominal sepsis impairs colonic reparative collagen synthesis. Am J Surg 171(1):102-107 (discussion 107-8)

25. Nishihara M, Aoki H, Ohno S, Furusho A, Hirakata S, Nishida N, Ito S, Hayashi M, Imaizumi T, Fukumoto $Y$ (2017) The role of IL-6 in pathogenesis of abdominal aortic aneurysm in mice. PLoS ONE 12(10):e185923

26. Rucinski J et al (2001) Closure of the abdominal midline fascia: meta-analysis delineates the optimal technique. Am Surg 67(5):421-426

27. Israelsson LA, Jonsson T (1993) Suture length to wound length ratio and healing of midline laparotomy incisions. Br J Surg 80(10):1284-1286

28. Diener MK et al (2010) Elective midline laparotomy closure: the INLINE systematic review and metaanalysis. Ann Surg 251(5):843-856

29. Ceydeli A, Rucinski J, Wise L (2005) Finding the best abdominal closure: an evidence-based review of the literature. Curr Surg 62(2):220-225 
30. Jargon D et al (2008) Risk factors and prevention of incisional hernia - what is evidence-based? ZentralblChir 133(5):453-457

31. Millbourn D, Cengiz Y, Israelsson LA (2009) Effect of stitch length on wound complications after closure of midline incisions: a randomized controlled trial. Arch Surg 144(11):1056-1059

32. Israelsson LA, Millbourn D (2013) Prevention of incisional hernias: how to close a midline incision. Surg Clin North Am 93:1027-1040

33. van Ramshorst GH, Klop B, Hop WC, Israelsson LA, Lange JF (2013) Closure of midline laparotomies by means of small stitches: practical aspects of a new technique. Surg Technol Int 23:34-38

34. Deerenberg EB, Harlaar JJ, Steyerberg EW, Lont $\mathrm{HE}$, van Doorn HC, Heisterkamp J, Wijnhoven BP, Schouten WR, Cense HA, Stockmann HB, Berends FJ, Dijkhuizen FPH, Dwarkasing RS, Jairam AP, van Ramshorst GH, Kleinrensink GJ, Jeekel J, Lange JF (2015) Small bites versus large bites for closure of abdominal midline incisions STITCH: a doubleblind, multicentre, randomised controlled trial. Lancet 386:1254-1260

35. MuysomsFE, Dietz UA (2016) Prophylakische Netze in Bauchdeckenchirurgie. Chirurg 87:751-761

36. Dasari M, WesselCB,HamadGG (2016) Prophylactic mesh placement for prevention of incisional hernia after open bariatric surgery: a systematic review and meta-analysis. Am J Surg 212:615-622

37. Muysoms FE, Detry O, Vierendeels $T$, Huyghe $M$, Miserez M, Ruppert M, Tollens T, Defraigne JO, Berrevoet $F$ (2016) Prevention of incisional hernias by prophylactic mesh-augmented reinforcement of midline laparotomies for abdominal aortic aneurysm treatment: a randomized controlled trial. Ann Surg 263:638-645 